\title{
W.M.A. Hendriks
}

\section{IN SEARCH OF THE ORIGINAL TEXT IN MARK 9:38}

\begin{abstract}
The text-critical situation of Mark 9:38 is very complicated. This complex situation already becomes evident in the different readings of the critical editions. While there is almost no variation in the first part of the verse, the critical editions offer four different readings in the last part of it. So there is until now no consensus at all. The question remains which text appears to be the more original one. Several scholars - such as Vaganay, Duplacy, Amphoux, and others - in search of the original text of Mark - opt for a so called Western text, the main stream still prefers the Neutral text of Westcott and Hort. A text-critical analysis of Mark 9:38 may provide an answer to this question.
\end{abstract}

\section{COMPLICATED TEXT-CRITICAL SITUATION}

The story of the strange exorcist in Mark 9:38-40 according to N28 runs as

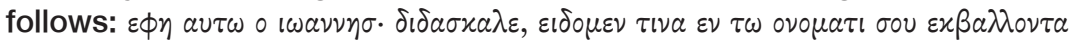

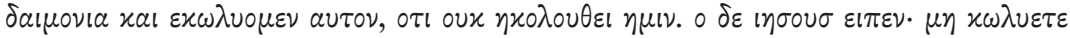

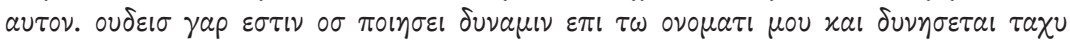

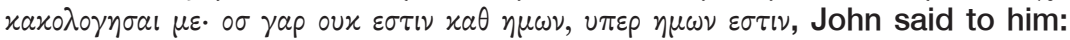
"Teacher, we saw someone in your name driving out demons and we tried to stop him, because he was not following us." Jesus said: "Do not stop him. For no one who will do a deed of power on my name will quickly be able to speak evil of me. Indeed, who is not against us, is for us."

The text-critical situation of verse 38 is very complicated. In the words of Dieter Lührmann (1987:166): “Textkritisch ist der Vers außergewöhnlich kompliziert, ohne daß daran viel für sein Verständnis hängt." This complex situation already becomes evident in the different readings of the critical editions. While there is almost no variation in the first part of the words of 


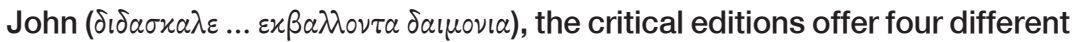
readings in the last part of the verse. So there is no consensus at all.

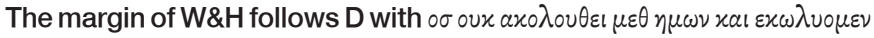

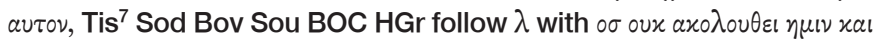

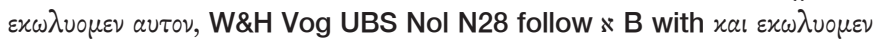

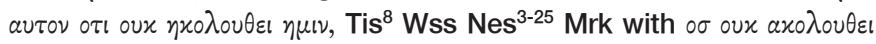

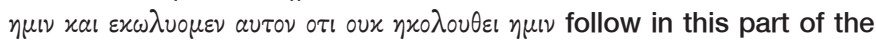
verse the conflate reading of the Byzantine text (with $\varepsilon x \omega \lambda \nu \nu_{\nu} \mu \nu$ instead of $\varepsilon x \omega \lambda \nu \sigma \alpha \mu \varepsilon v$ and $\eta x 0 \lambda \circ \nu \theta \varepsilon l$ instead of $\alpha x_{0} \lambda \circ \nu \theta \varepsilon l$ of TR).

\section{IN SEARCH OF THE ORIGINAL TEXT}

In fact, Hort (1881:120) made it quite clear that the earliest readings which can be fixed chronologically are so called Western readings and that the most widely spread text was the so called Western text. Nevertheless, as is known, Westcott and Hort chose the so called Neutral text as the more original one. The question remains which text appears to be more original. Maybe the Western text? Some indications will be given.

At the Lille colloquium in 2000 I read a paper concerning the textual variation in the Gospel of Mark, illustrated by an analysis of Mark 6:33 (Hendriks 2003). This verse is so to say the cornerstone of the argumentation of Hort in favour of the priority of the text of the codices $\mathrm{N}$ and $B$. Hort (1881:95) divides the readings as follows into three groups: $\alpha$

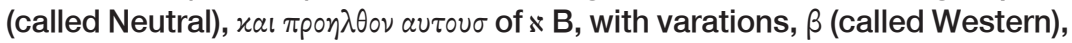

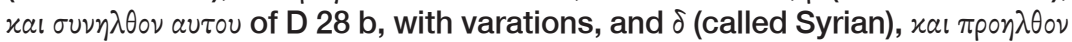

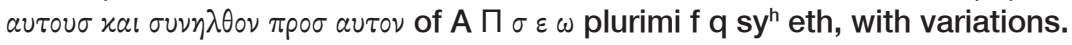
His main point is the conflation of $\alpha$ and $\beta$ found in $\delta$. However, Hort did

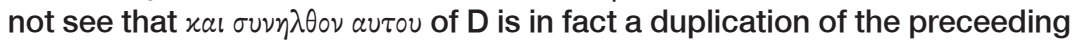

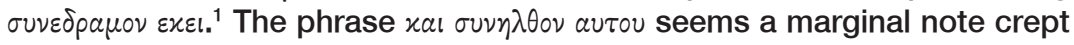
into the text. So the following sketch of the transmission of Mark 6:33 has been proposed. Now with the insertion of $\phi 788$ as reading 3 , according to Lafleur (2013:288) (with $1 \delta \omega \nu$ written instead of $\varepsilon 1 \delta \circ v)$. Only the six main types are recorded here.

1 The words $\varepsilon x \varepsilon l$ (there, in that place) and avтou (just there) have the same local

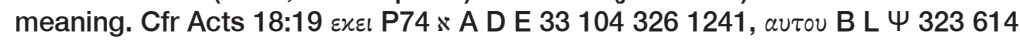
945117515051739 plurimi. 


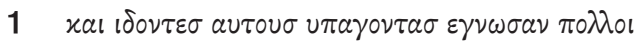
$\lambda 205-209$

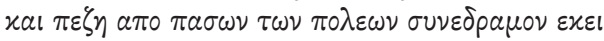

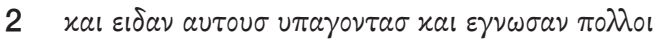

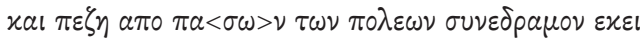

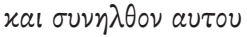

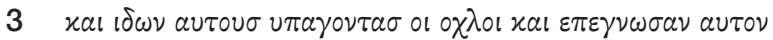

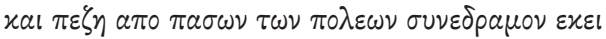

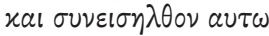

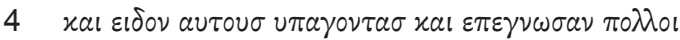

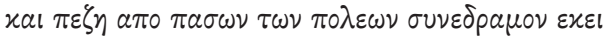

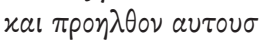

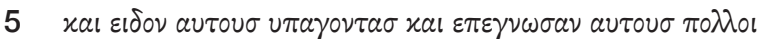

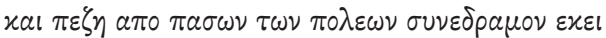

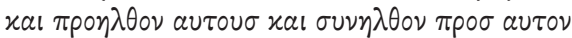

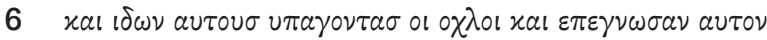

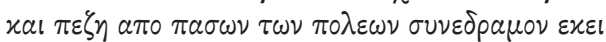

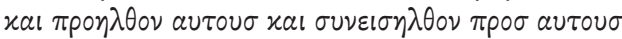

The shorter reading found in $\lambda 205-209$ is head of the transmission (Ausgangstext). ${ }^{3}$

In the Revue Biblique I wrote an article with respect to Hort's second example of a conflate reading in the majority text, namely Mark 8:26 (Hendriks 2007). According to Ernst Lohmeyer, the accepted text (Legg $1935, \mathrm{Nes}^{25}$ ) of this verse is ununderstandable. ${ }^{4}$ Very few authors allude to the reading of Codex Bezae D.05 as being head of the transmission. ${ }^{5}$

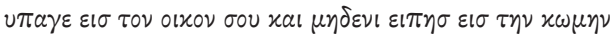

$$
\begin{aligned}
& \text { vade in domum tuam et nemini dixeris in vico } \\
& \text { go to thy house and tell no one in the village }
\end{aligned}
$$

This reading of $D d(q)$ fits nicely in the context. From this all other readings can be explained. Some authors refer to the African text of $\mathrm{c} \mathrm{k}$ $\left[\mathrm{W} \& \mathrm{H}^{\mathrm{mg}}\right]$ as being original. ${ }^{6}$ I suggested an accidental loss of $\nu \pi \alpha \gamma \varepsilon \varepsilon \varepsilon \sigma \tau \nu$ olxov rou in these two witnesses (cfr Mark 2:11 and 5:19).

\footnotetext{
2 A.02 repeats $\sigma u \nu \varepsilon \delta p a \mu \nu v$ at the place of $\sigma u \nu \eta \lambda \theta 0 \nu$.

3 For the shorter reading principle see Hendriks (2005, 2011).

4 Lohmeyer (1967:159): "Auch sachlich wäre ein Befehl: 'Gehe nicht in das Dorf!' unverständlich. Wohnt der Blinde nicht im Dorf, so ist er überflüssig; steht 'sein Haus' aber im Dorf, so ist er unsinnig."

5 Explicitily only Allen (1915: 116).

6 So among others Lohmeyer (1967:158).
} 
Hereafter I will discuss Hort's third example of conflation in the majority text, namely Mark 9:38. His fourth example concerning Mark 9:49 has been discussed elsewhere (Hendriks 2014).

\section{THE COMMON VIEW: HORT AND METZGER}

Hort (1881:100-101) gives the documentary attestation of Mark 9:38

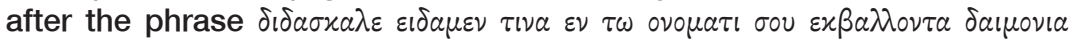
as follows. ${ }^{7}$ In some points the table has been adapted to present-day conventions.

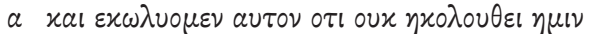

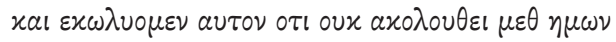

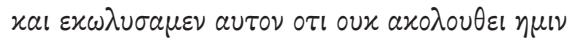

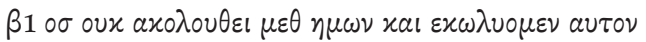

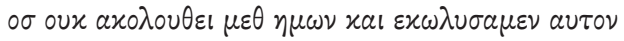

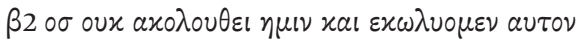

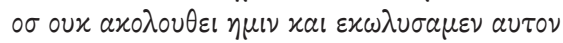

$$
\begin{aligned}
& \text { s B } \Delta \\
& \text { L } \\
& \text { C } \text { curs }^{3} \mathrm{f} \mathrm{sy}^{\mathrm{p}} \text { syj bo eth }
\end{aligned}
$$

D

a k

$\lambda 1-209$

X $\varphi 13-69-34628$ alii $^{4}$

b c ff ${ }^{2}$ i vg symg arm

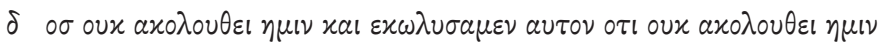

A N EFGH KM SUV

$\Gamma$ П curs $^{\text {multi }}$ sy $^{\text {h }}$ got

(in reading $\delta 565$ has $\eta \varkappa 0 \lambda \circ \nu \theta \varepsilon เ$ and alii ${ }^{1} \mu \varepsilon \theta \eta \mu \omega \nu$ in the first clause and alii ${ }^{2}$ $\mu \varepsilon \theta \eta \mu \omega \nu$ in the third)

According to Hort part of the confusion of readings is due to obvious

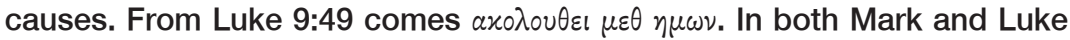
there is an inclination to alter imperfects into aorists and so the variant $\varepsilon \chi \omega \lambda \cup \sigma \alpha \mu \varepsilon \nu$ in these gospels can be explained. Besides assimilation to Luke there is a transposition in reading $\beta$ of the last clause to bring it into

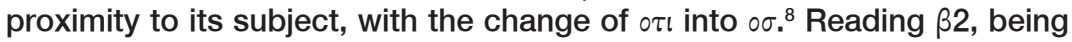
the most widely spread, has $\eta \mu \iota \nu$ in conformity with reading $\alpha$. Finally the

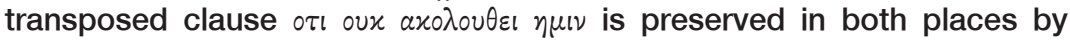
reading $\delta$ with exact similarity of ending. This resulting conflate reading is not supported by any early version. So far the interpretation of Hort (1882:101).

7 Hort reads $\varepsilon 1 \delta a \mu \varepsilon \nu$ (with $\alpha$ as in $\mathrm{D} \mathrm{N} \Sigma \Psi 346$ ). He notes that 33 is defective.

8 According to Ross (1983:63): "this is hardly a sufficient motive for so radical an alteration." 
One might make the following two remarks. Firstly: more important than a supposed inclination to alter imperfects into aorists in both Mark and Luke is the actual preference for the imperfect in the gospel of Mark and for the aorist in the gospel of Luke. The historical books of the LXX show a high percentage of narrative aorists (some $78 \%$ ) as compared with the Hellenistic historical literature (some $42 \%$ ). Luke Matt Mark (in this order) are in between. So in this respect Mark is the more Hellenistic writer, furthest away from the Semitic world.

Secondly: Luke's actual preference for the aorist is not seen in the

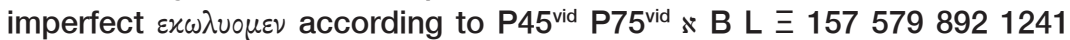
a b e I arm geo, which imperfect here in Luke 9:49 might be the more original one. Apart from Tis and TR the editions read $\varepsilon x \omega \lambda \nu$

Bruce Metzger (1994:86) follows Hort with a too dense survey. Apart from many minor variations, he gives the following principal readings (for the witnesses of each reading see also N28).

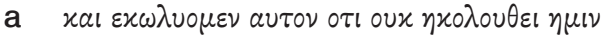 "and we forbade him, because he was not following us"

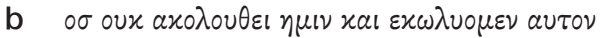
"who does not follow us, and we forbade him"

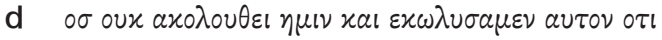

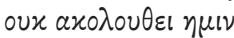
"who does not follow us, and we forbade him, because he does not follow us"
« $B \Delta \Theta \Psi$ sys $^{s}$ sy $^{p}$ sy $^{j}$ alii
(D) $\lambda$ alii (alii)

According to Metzger (1994:86) reading $d$ is a conflation that presupposes the existence of the other two. He prefers reading a because of superior witnesses and because in reading $b$ there has been $a$ transposition of the last clause to bring it into proximity to its subject (with the change of $\circ \tau \iota$ into $\circ \sigma)$. However, like Hort, also Metzger forgets that sometimes minor variations may form a key to a solution. Among others Robert Stein follows Metzger. ${ }^{9}$

\section{PLEA FOR THE WESTERN READING}

The approach of Hort and Metzger is surely not the only one. Lagrange

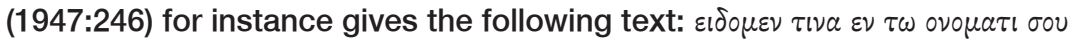

9 Stein (2008:451) adds: "The other variants involve primarily differences in tenses and in the order of the clauses; $\varepsilon \varkappa \omega \lambda \nu \circ \mu \varepsilon \nu$ is a tendential/conative imperfect." Precisely the order of the clauses is my main concern. 


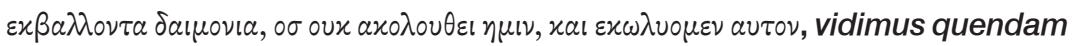
in nomine tuo eicientem daemonia, qui non sequitur nos, et prohibuimus eum, nous avons vu quelqu'un qui chassait des démons en ton nom, qui ne nous suit pas, et nous l'avions empêché. Lagrange prefers the text of von Soden (and of Tischendorf without the last phrase) to that of WestcottHort and Vogels. It is the text of family $\lambda$ and the Latin vulgate. Lagrange

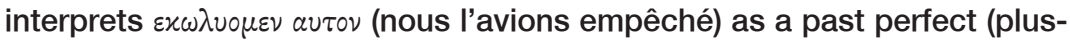
que-parfait), and considers prohibuimus eum (nous l'avons empêché) of the vulgate as stronger (less anxious). ${ }^{10}$

Vincent Taylor (1966:406-407) puts forward more or less the same view

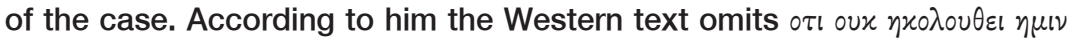

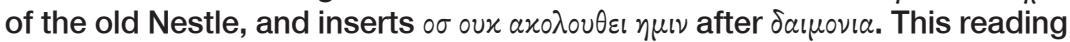
(see below sub 1) should be preferred to that of the W\&H text, in spite of its support in $\mathrm{B}$, for the reading with $\circ \tau \iota$ in $38 \mathrm{~b}$ may be an assimilation

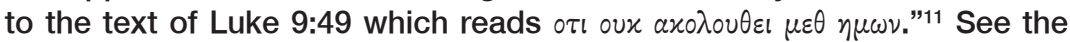
following summary.

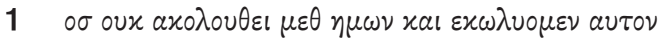

D a k

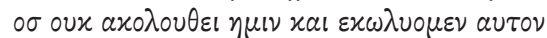

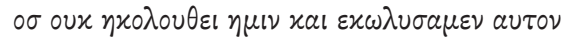
$\lambda(\phi 28700) b c f^{2}$ i arm W 565

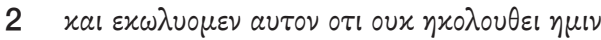
« B (C, L) $\Delta \Theta$ sys alii

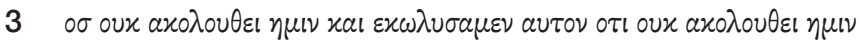

plurimi

Charles Cranfield (1966:310) joins Taylor: "Probably we should follow

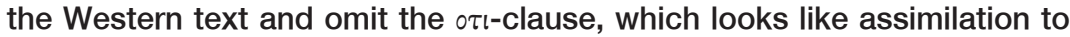
Luke." Maybe Lagrange and Taylor and Cranfield deserve more attention.

\section{ANALYSIS OF MARK 9:38}

Beforehand something must be said about the Greek witnesses and the versional evidence. As to the Greek readings, use has been made of Text und Textwert (TTW) edited by Kurt and Barbara Aland (1998:259-265). However, some uncials are not recorded in TTW. ${ }^{12}$ In addition, there may be some errors. Therefore New Testament Greek Manuscripts edited by

10 Lagrange (1947:247): «L'imparfait $\varepsilon \varkappa \omega \lambda \nu о \mu \varepsilon \nu$ semble indiquer cette inquiétude: nous l'avons empêché (Vulgate etc) serait plus ferme."

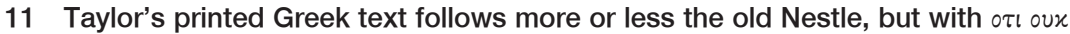

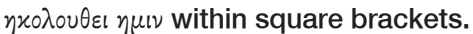

12 For the questionable reason see Aland-Aland (1995:103). 
Reuben Swanson (1995:150) has been consulted, together with other sources, including reproductions and the like. ${ }^{13}$

The following families with their symbols are used.

$\lambda=111820520915822193$ (f1)

Lake, TTW

$\phi=13691243465437888268289831689$ (f13) TTW, Lafleur

$\sigma=34951795414241675$ (f1424) (if 3 out of 5) TTW

$\pi=\mathrm{K} \sqcap 1142654891079121913461816(\mathrm{Ka}) \quad$ New, Geerlings

$\varepsilon=\mathrm{EF} \mathrm{G} \mathrm{H}(\mathrm{Ki})$

Geerlings

$\omega=\mathrm{S} \vee \Omega(\mathrm{KI})$

Geerlings

As to the versional evidence, the question arises in which language the versional readings will be given. According to Tjitze Baarda (1994:60), the most appropriate way in recording them would be to give verbatim quotations in the original script, but without translation this would be of little benefit for those who do not know these languages. Therefore I prefer to provide the readings in question in the language of the sources used.

\begin{tabular}{|c|c|c|}
\hline Latin & $a b c d f f f^{2} i k \mid q r^{1} r^{2} z \delta$ & Itala, editions $(z=$ aur $=15)$ \\
\hline Syriac & sy $^{\mathrm{s}} \mathrm{sy}^{\mathrm{p}} \mathrm{sy}^{\mathrm{h}} \mathrm{sy}$ & Kiraz, White, Land \\
\hline English & sa bo & Horner \\
\hline French & arm & Künzle ${ }^{14}$ \\
\hline English & eth & Zuurmond \\
\hline Latin & $\mathrm{geo}^{1} \mathrm{geo}^{A} \mathrm{geo}^{\mathrm{B}}$ & Blake \\
\hline Greek & got & Streitberg $^{15}$ \\
\hline
\end{tabular}

Below one finds a survey of variants in Mark 9:38 (after $\varepsilon ı \delta \circ \mu \varepsilon \nu \tau \iota \nu a \varepsilon \nu \tau \omega$

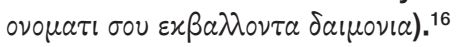

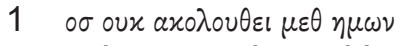
qui non sequitur nobiscum qui non sequitur nobiscum qui non sequitur nobiscum qui nobiscum non it

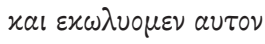
et vetuimus illum et prohibuimus illum et prohibuimus eum et prohibuimus eum
D W\&H ${ }^{m g}$ k a d Augustine ${ }^{17}$ geo ${ }^{1}$

13 Reproductions (P45 A B W $\Delta$ ), microfilms (28 33700 892), facsimilia (x B C L $\Theta$ ), and editions (A C D N $\Sigma \Phi \Psi 0274 \lambda \phi \varepsilon \omega 565579$ ).

14 Using the Lexicon.

15 The Greek agrees with the Gothic: saei ni laisteip unsis, jah waridedum imma, unte ni laisteip unsis.

16 Absent witnesses: P45 P84 P88 P 33 e n t.

17 Augustine (De consensu evangelistarum 4.5), CSEL 43, 398. 


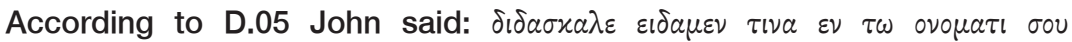

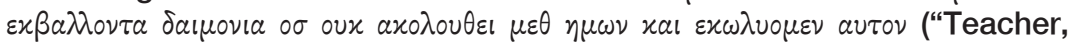
we saw someone in your name driving out demons who does not follow with us, and we tried to stop him"). This sentence is well constructed: the impersonal $\tau \iota \nu \alpha$ is explicated by the phrase $\circ \sigma$ ou $\alpha x 0 \lambda \circ u \theta \varepsilon \iota \mu \varepsilon \theta \eta \mu \omega \nu$, and the last phrase says that the disciples tried to stop that person. Jesus responds: do not stop him. It is evident that the phrases are given in the right order: someone is seen who does not follow with us, we tried to stop him, Jesus replied: do not do that. The evangelist writes the better Greek. The vetus latina followed by Augustine translates $\mu \varepsilon \theta \eta \mu \omega \nu$ with nobiscum, and understands $\varepsilon x \omega \lambda \nu \circ \mu \varepsilon \nu$ as a perfect tense, not as an imperfectum de conatu.$^{18}$ I suppose that both $\mu \varepsilon \theta \eta \mu \omega \nu$ and $\varepsilon x \omega \lambda \nu \circ \mu \varepsilon \nu$ are presynoptic. ${ }^{19}$ The

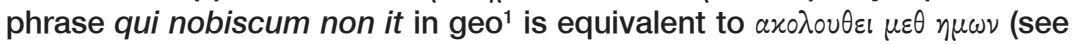
sys and sy' hereafter sub 4).

\begin{tabular}{|c|c|c|}
\hline$\circ \sigma o u x a x o \lambda \circ v \theta \varepsilon l \eta \mu l \nu$ & 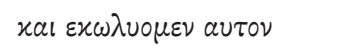 & $\lambda($ exc 118 \\
\hline 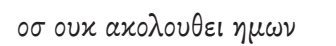 & 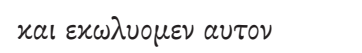 & 2100 \\
\hline qui non sequitur nos & et prohibuimus illum & \\
\hline qui non sequitur nos & et proibuimus eum & \\
\hline qui non sequitur nos & et prohibuimus eum & $\begin{array}{r}\text { gat i I } \\
\text { Ps-Jerome }\end{array}$ \\
\hline quia non sequitur nos & et prohibuimus eum & \\
\hline qui non se[quitur no]s & et prohibuimus eum & \\
\hline וכליניהי & הו דלי נקף לן & \\
\hline \multicolumn{3}{|c|}{ et il ne faisait pas partie des nôtres ${ }^{21}$ et nous l'empêchions } \\
\hline qui non sequitur nos & et prohibuimus eum & \\
\hline qui non sequitur nos & et nos prohibuimus eum & \\
\hline
\end{tabular}

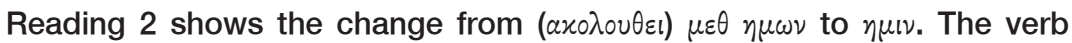
axo $00 \theta \varepsilon \omega$ is usually constructed with the dative (with $\mu \varepsilon \tau \alpha \tau i v o \sigma$ apart from Mark 9:38 and Luke 9:49 also in Rev 6:8 and 14:13, with $\circ \pi \imath \omega \omega \tau \iota \nu \circ \sigma$ in Matt 10:38 and Mark 8:34). So here one finds a change from unusual to common. Minor changes: quia ex errore q, explicative addition of nos $(\eta \mu \varepsilon เ \sigma) \mathrm{geo}^{\mathrm{B}}$.

18 See BDF § 326. Nor as a plusquamperfectum.

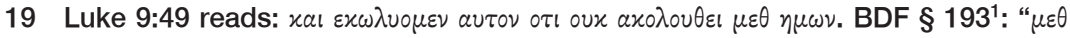
$\eta \mu \omega \nu$ not follow us, but follow [you] together with us."

20 Pseudo-Jerome (In evangelium secundum Marcum 9.38), PL 30, 616.

21 Litterally: and does not go behind us (so Baarda, by email). 


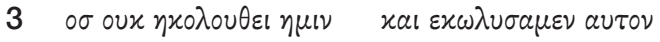

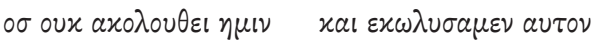

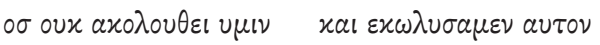

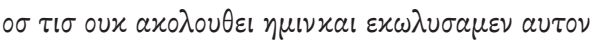

W (so ms, error in

TTW) 565

$\mathrm{X} \phi$ (exc 346) 28700

$1241 \sigma 1424$

$\phi 346$

2542

Like the Latin translators reading 3 interprets $\varepsilon \varkappa \omega \lambda \nu 0 \mu \varepsilon \nu$ not as an imperfectum de conatu, with no indication as to whether the act is momentary or not: $\varepsilon x \omega \lambda \cup \sigma \alpha \mu \varepsilon v$, we forbade him, we stopped him. Codices

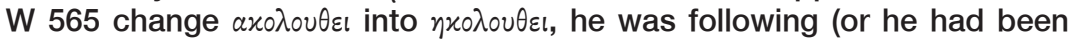

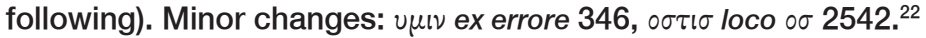

\begin{tabular}{|c|c|c|}
\hline 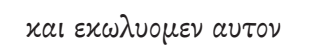 & 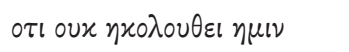 & $\approx \mathrm{B} \Delta \Theta$ \\
\hline 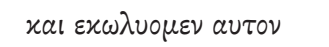 & 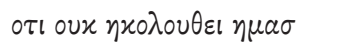 & 2427 \\
\hline 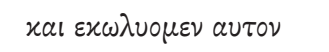 & 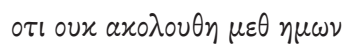 & L (so Tis $\left.{ }^{\text {ed }}\right)$, cfr Luke 9:49 \\
\hline 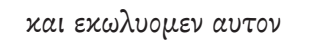 & 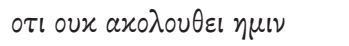 & $\Psi($ edition $a x-$, TTW $\eta x-)$ \\
\hline 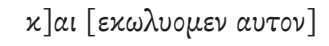 & 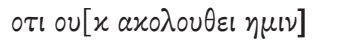 & 0274 \\
\hline 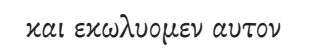 & 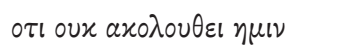 & 892 \\
\hline et prohibuimus eum & quia non sequitur nos & $f z \delta$ \\
\hline וכליניהי על דלא אתא בתרן & & sys \\
\hline וכליניהי על דלא נקף לן & & $\mathrm{sy}^{\mathrm{p}}$ \\
\hline וכלינן יתה דלא בתרן & & sy \\
\hline $\begin{array}{l}\text { and we forbade him, } b \\
\text { was not following you }\end{array}$ & $\begin{array}{l}\text { ecause he } \\
\text { with us }\end{array}$ & eth \\
\hline
\end{tabular}

In reading 4 one finds an inversion of the two phrases: first the prohibition, thereafter the reason of it $(\circ \sigma$ becomes $\circ \tau)$. As in readings 1 and 2 the

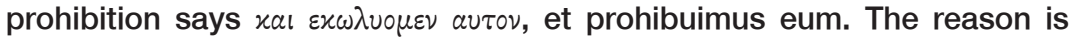

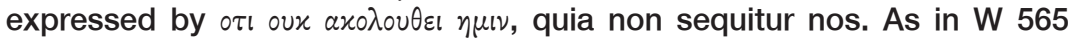

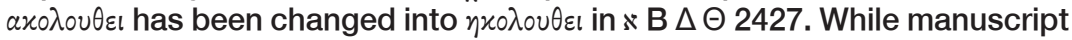

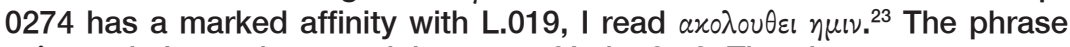
$\mu \varepsilon \theta \eta \mu \omega \nu$ in L may be a reminiscence of Luke 9:49. The phrase $\varepsilon \rho \chi \varepsilon \tau \alpha \iota ~ o \pi l \sigma \omega$

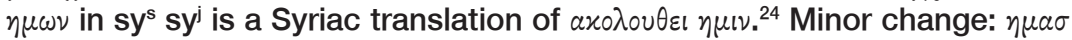
loco $\eta \mu \nu 2427$.

22 BDF § 293: "The definite relative $\circ \sigma$ and the indefinite relative $\circ \sigma \tau / \sigma$ are no longer clearly distinguished in NT."

23 See Plumley - Roberts (1976:42), with note 45: "168-70: These lines are barely

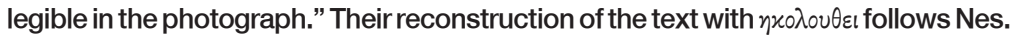

24 For sy' see Land (1875). 


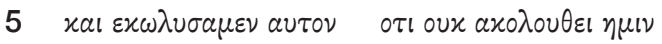

C 1071

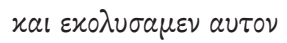

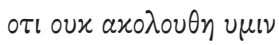

579 (so Swanson)

xal $\varepsilon x \omega \lambda \nu \sigma \alpha \mu \varepsilon \nu$ avtov

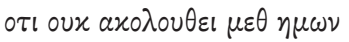

1342, cfr Luke 9:49

we forbade him

because that he walks not with us

sa bo

Also in reading 5 the aorist $\varepsilon \varkappa \omega \lambda \nu \sigma a \mu \varepsilon \nu$ of reading 3 does not indicate whether the act is momentary or not: we forbade him. The words $\mu \varepsilon \theta \eta \mu \omega \nu$ in 1342 (cfr sa bo eth) may be a reminiscence of Luke.

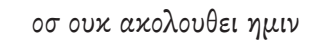

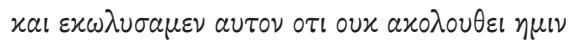

A П also M N U Y $\Gamma \sum 0211 \sigma \pi \varepsilon \omega 1181572193^{\circ}$ plurimi got TR

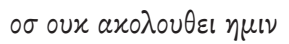

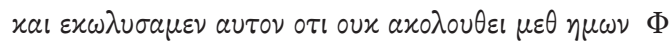

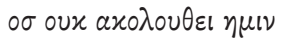

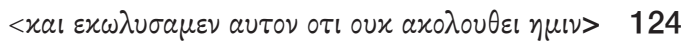
$\div$ - מתל דלא נקר לן 25 הו דלא נקף לן וכליניהי sy

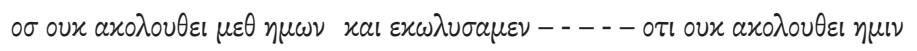

Bas

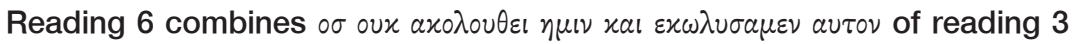

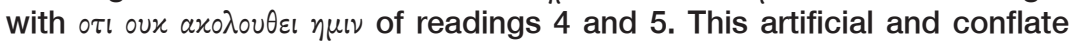
reading of $A \Pi$ is found in 1391 witnesses. ${ }^{25}$ Again $\mu \varepsilon \theta \eta \mu \omega \nu$ in $\Phi$ and Basil may be a reminiscence of Luke 9:49. Minor change: omission of autov in Bas. ${ }^{26}$ The phenomenon homoioteleuton is found in 122 witnesses. In addition to $\phi 124$ I mention explicitly $131174 \sigma 349 \pi 1816$. Likewise in an

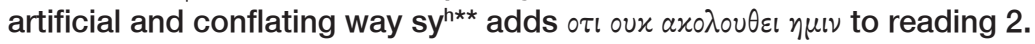

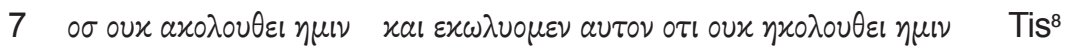

Finally, some critical editions provide in this part of the verse the byzantine text (with $\varepsilon x \omega \lambda \nu \circ \mu \varepsilon v$ instead of $\varepsilon x \omega \lambda \nu \sigma \alpha \mu \varepsilon \nu$ and $\eta x 0 \lambda \circ v \theta \varepsilon เ$ instead of $\alpha x \circ \lambda \circ v \theta \varepsilon l$ of TR). These are Tis ${ }^{8}$ Wss Nes $^{3-25}$ Mrk.

After this survey of the succession of readings the following summary may be given.

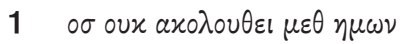

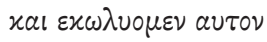

D a d k Aug geo' $W \& H^{m g}$

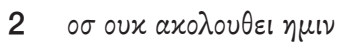

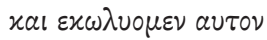

$\lambda$ b c ff $^{2}$ gat i l (q) r $^{1} r^{2}$ vg Ps-Jer syhmg arm geo ${ }^{2}$ Tis $^{7}$ Sod Bov Sou BOC HGr

25 I refer to Text und Textwert, herausgegeben von Aland - Aland (1998:259-265).

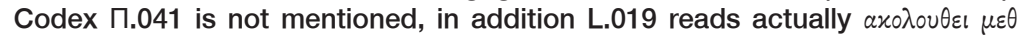
$\eta \mu \omega \nu$, and W.032 actually $\eta x 0 \lambda 0 v \theta \varepsilon \varepsilon$.

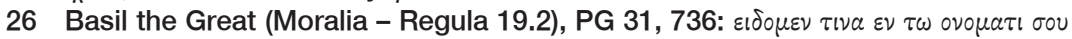

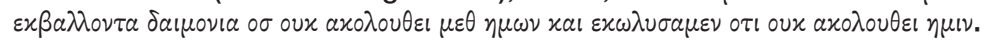




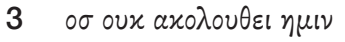

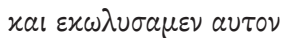

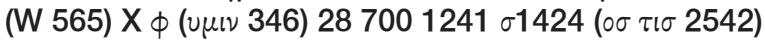

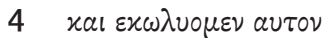

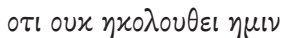
x B $(L, \Psi 0274892,2427) \Delta \Theta f z \delta s^{s}$ sy $^{p}$ syj eth W\&H Vog UBS Nol N28

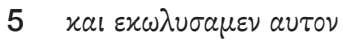
C 5791071 (1342) sa bo

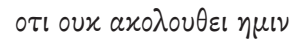

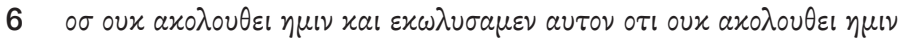
A M N U Y $\Gamma \Sigma(\Phi) 0211 \sigma \pi \varepsilon \omega 1181572193^{\mathrm{c}}$ plurimi (Bas) sy ${ }^{\mathrm{h}}$ got TR (homtel $\phi 124131174 \sigma 349 \pi 1816$ )

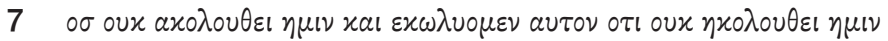
$\mathrm{Tis}^{8}$ Wss $\mathrm{Nes}^{3-25}$ Mrk

\section{CONCLUDING REMARKS}

First of all it has become evident that Codex Bezae D.05 provides the

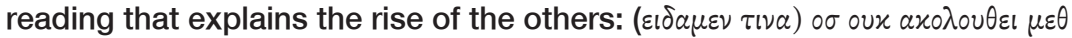
$\eta \mu \omega \nu$ xal $\varepsilon x \omega \lambda \nu 0 \mu \varepsilon \nu$ avtov, (videmus quemdam) qui non sequitur nobiscum et prohibuimus eum, (we saw someone) who does not follow with us and we tried to stop him. ${ }^{27}$ Immediately hereafter follows: Jesus said: do not stop him. The edition of Westcott and Hort gives this reading in the margin. Maybe this reading is at the same time presynoptic (see below).

The second reading (family $\lambda$ and several old versions) with axo $\lambda \circ v \theta \varepsilon l \eta \mu l \nu$ is found in Tis ${ }^{7}$ Sod Bov Sou BOC HGr. It is preferred by Taylor, Cranfield, and likewise by Ernst Haenchen (1966:327): "Die Worte 'weil er uns nicht folgt' (Nes $\left.{ }^{17}\right)$ könnten ein späterer Zusatz sein." The third reading, found in (W 565) X ф 2870012411424 (2542), with $\varepsilon x \omega \lambda \nu \sigma \alpha \mu \varepsilon \nu$ instead of $\varepsilon x \omega \lambda \nu \circ \mu \varepsilon \nu$, is not found in any modern critical edition. The transposition of the two phrases in the fourth reading ( $\mathrm{B}$ (L) etc) is followed by W\&H Vog UBS Nol N28. This means that the new Nestle (SQE $\left.{ }^{15} U_{B S}{ }^{4} N^{2} 8^{1}\right)$ follows $W \& H^{t x t}$, and not the conjectural emendation of the old Nestle. The text behind the versions ( $\mathrm{z} \delta$ ) is not certain. The fifth reading (C 5791071 (1342)) provides $\varepsilon \chi \omega \lambda \nu \sigma a \mu \varepsilon \nu$ (as in reading 3 ). The artificial sixth reading has been composed out of readings 3 and 5 (conflation). The likewise artificial seventh reading seems to be a conjectural emendation of reading 6, with $\varepsilon x \omega \lambda \nu \circ \mu \varepsilon v$ instead

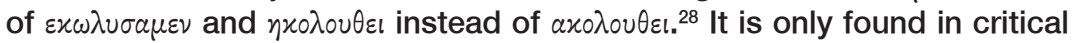
editions (since $\mathrm{Tis}^{8}$ ).

27 Latin et prohibuimus eum: and we stopped him.

28 See Lührmann (1987:166): "Tischendorfs Konjektur, die bis Nes ${ }^{25}$ übernommen war, ist in N26 und bei Greeven [HGr] aufgegeben, freilich mit unterschiedlichen Ergebnis. Die Bezeugung für die Textfassung von N26 ist zwar quantitativ 
The reading of Mark 9:38 in Codex Bezae can be presynoptic. I consider as presynoptic the reading that explains the rise of the readings of Matt and Mark and Luke. Apart from this Bezan reading, one finds the phrase $\mu \varepsilon \theta \eta \mu \omega \nu$ (or equivalent) in $L \Phi 1342$ eth Basil. As has been said, it may be a reminiscence of Luke 9:49. Or rather a reminiscence of a presynoptic reading. Here are three examples (including Mark 9:38) of a supposed presynoptic reading as compared with the reading of the synoptic gospels.

Presynoptic $\quad$ $\alpha \iota \varepsilon \varepsilon \theta \varepsilon \omega \sigma a \lambda \varepsilon x \tau \omega \rho \varepsilon \phi \omega \nu \eta \sigma \varepsilon \nu$

Matt 26:74 $\quad$ $\alpha \iota \varepsilon \varepsilon v \varepsilon \omega \omega \sigma \alpha \lambda \varepsilon x \tau \omega \rho \varepsilon \phi \omega \nu \eta \sigma \varepsilon \nu$

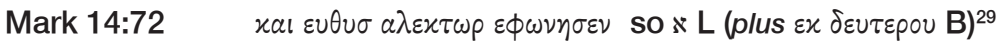

John 18:27 xal $\varepsilon \cup \theta \varepsilon \omega \sigma \alpha \lambda \varepsilon x \tau \omega \rho \varepsilon \phi \omega \nu \eta \sigma \varepsilon \nu$

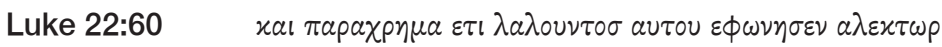

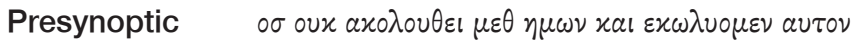

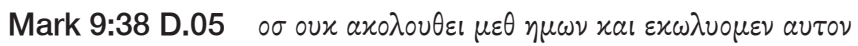

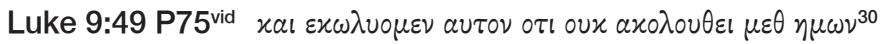

Luke 9:49 afra et vetabamus illum quia non sequitur nobiscum

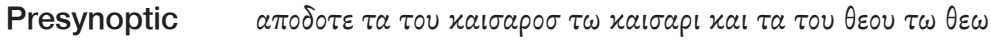

Luke 20:25 D.05 a

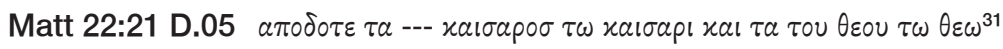

Mark 12:17 D.05 a

In the last example the Bezan text provides in a perfect balance a pure parallelism (more so than in the official readings of this synoptic saying): send what comes from Caesar back to Caesar and what comes from God back to God. Paraphrased: give what bears the image of Tiberius back to Tiberius and what bears the image of God back to God (= give the man back to himself, show respect to a human being). It is N28 that provides free (read uncontrolled) variants of this saying of Jesus: Luke adds tolvov,

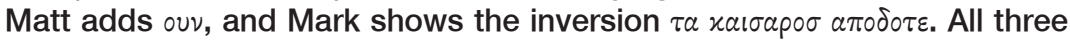
provide $x a l \sigma \alpha \rho \circ \sigma$ and $x a l \sigma \alpha \rho$ without the article. ${ }^{32}$

gering ( $\mathrm{B} \Delta \Theta 0274 \mathrm{pc} \mathrm{f} z \mathrm{sy}^{\mathrm{s}} \mathrm{sy}^{\mathrm{p}}$ ) und steht ebenfalls unter dem Verdacht der Beeinflussung durch Lk 9,49, kann sich aber immerhin auf $x$ und B stützen."

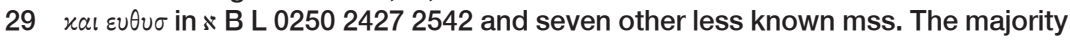
reads $\varepsilon \cup \theta \varepsilon \omega \sigma$ instead of $\varepsilon \nu \theta \nu \sigma$.

30 Luke 9:49 according to (sine avtov P45 vid) P75 א B L $\equiv 1575798921241$ a b e I arm geo.

31 Accidental loss of tou.

32 Nota bene: $x a$ loap with the article refers to the actual imperator Tiberius. 


\section{METHODOLOGICAL NOTE}

As to the approach of Hort, the following may be observed. It is not only that he prefers the so called Alexandrian reading (Alpha text-type) to the so called Western reading (Delta text-type), but also that he distinguishes merely three categories $(\alpha \beta \delta)$, whereas one sometimes has to divide the readings into more categories (multiple main readings). The summary above presents six readings from manuscripts instead of merely three categories by Hort. Therefore the following methodological note is needed.

In 1881 Hort examined the Posteriority of Syrian readings to Western and Neutral readings shown by analysis of conflate readings, as I have shown in the foregoing pages. In 1911 Edward Ardron Hutton (1911) urged the use of what he called triple readings: he published a list of readings in which the Alexandrian and Western and Syrian authorities divide. According to Ernest Cadman Colwell (1969:27), Hutton's work is far from perfect. In a note on the same page Colwell reminds us that modern obsession with three text-types is derived from Jerome's preface to Chronicles, rather than from a study of manuscript groupings based upon readings. ${ }^{33} \mathrm{He}$ concludes with the remark that the New Testament manuscript material (which provides a multiple of different readings) is too varied to fit into only three text-types. So Colwell speaks of multiple readings. According to Frederik Wisse (1982:29)

The multiple readings give much more detail than Hutton's tool. ... Colwell has a much better range of existing textual groups, and hence will end up with much less ambiguous results.

Nevertheless, Metzger $\left(1994: 15^{\star}-16^{*}\right)$, in the second edition of his Textual Commentary, maintains (actually returns to) the division into three categories of witnesses: Alexandrian, Western, Byzantine.

At the Lunel Colloquium of 1994 (Hendriks 1996:235-237) I proposed a division into eight readings of Mark 5:21, with as the first xaı $\delta$ la $\pi \varepsilon p a \sigma a v \tau \circ \sigma \tau 0 v$

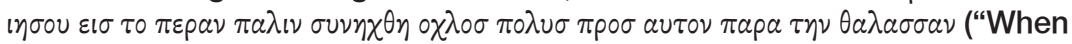
Jesus had crossed to the other shore, much people again gathered round him by the lakeside," of D.05. In the Revue Biblique (Hendriks 2005:581-587) I described six different readings of Matt 6:33 found in the fathers, with

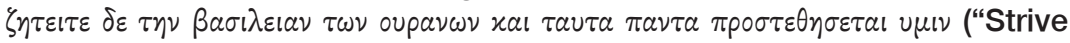
for the kingdom of heaven and all these things shall be added to you," of Justin). In the Revue Biblique (Hendriks 2007:266-271) I divided Mark 8:26

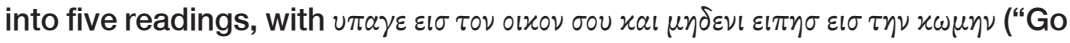

33 Concerning Jerome's preface to Chronicles I refer to Aland (1995:65-66). For the text of Jerome's preface see Weber (1975:546-547). 
to your house and tell no one in the village", of D.05) again as being the head of the transmission. Let these examples be sufficient.

From a methodological point of view the fact of multiple readings within the same variation unit must be preferred to a theoretical division into only three categories. So Hort makes a methodological error.

\section{BIBLIOGRAPHY}

Aland, K. \& Aland, B.

1995. The text of the New Testament: An introduction to the critical editions and to the theory and practice of modern textual criticism. Second Edition (paperback). Grand Rapids (MI): Eerdmans.

1998. Text und Textwert der griechischen Handschriften des Neuen Testaments (= TTW). Band 4,1,2. Das Markusevangelium. Berlin - New York: De Gruyter. ANTF 27.

2012. Novum Testamentum Graece. Begründet von Eberhard Nestle und Erwin Nestle. Herausgegeben von Barbara und Kurt Aland, Johannes Karavidopoulos, Carlo Maria Martini, Bruce M Metzger, 28. revidierte Auflage. Stuttgart: Deutsche Bibelgesellschaft [= N28].

Allen, W.C.

1915. The Gospel according to Saint Mark: With introduction and notes. London: Rivingtons. OCBC.

BAARDA, T.

1994. What kind of critical apparatus for the New Testament do we need? The case of Luke 23:48. In: B. Aland - J. Delobel (eds), New Testament textual criticism, exegesis, and early church history: A discussion of methods (Kampen: Kok Pharos, Contributions 7), pp 37-97.

Colwell, E.C.

1969. Studies in methodology in textual criticism of the New Testament. Leiden: Brill. NTTS 9.

Cranfield, C.E.B.

1966. The Gospel according to Saint Mark: An introduction and commentary: With additional supplementary notes. Cambridge: University Press. CGTC.

HAENCHEN, E.

1966. Der Weg Jesu: Eine Erklärung des Markus-Evangeliums und der kanonischen Parallelen. Berlin: Alfred Töpelmann. Sammlung Töpelmann 2,6.

HendRiks, W.M.A.

1996. Leçons pré-alexandrines du Codex Bezae dans Marc. In: D.C. Parker, C.-B. Amphoux (eds), Codex Bezae: Studies from the Lunel Colloquium, June 1994 (Leiden: Brill, NTTS 22), pp. 232-239. 
2003. Variation textuelle dans l'Evangile selon Marc (illustrée par Mc 6,33). In: C.-B. Amphoux - J.K. Elliott (eds), The New Testament text in early Christianity: Proceedings of the Lille colloquium, July 2000 (Lausanne: Du Zèbre, HTB 6), pp 349-367.

2005. Brevior lectio praeferenda est verbosiori. Revue Biblique 112(4):567-595.

2007. Mc 8:26: ne le dis à personne dans le village. Revue Biblique 114(2):255-272.

2009. Lectio e qua caeterarum ortus facillime explicetur [Mark 1:4.5.16.28.29]. Filología Neotestamentaria 22:3-39.

2011. Internal evidence of readings. Estudios Bíblicos 69:301-322.

2014. The case for the primacy of the Western Text. Estudios Bíblicos 72:411-436.

HORT, F.J.A.

1881. The New Testament in the original Greek. Vol II, Introduction \& Appendix. Cambridge - London: Macmillan.

HutTon, E.A.

1911. An atlas of textual criticism: Being an attempt to show the mutual relationship of the authorities for the text of the New Testament up to about 1000 AD. Cambridge: University Press.

LAFLEUR, D.

2013. La Famille 13 dans l'évangile de Marc. Leiden - Boston: Brill. NTTSD 41.

LAGRANGE, M.-J.

1947. Evangile selon Saint Marc. Paris: Gabalda et Cie. Etudes Bibliques.

LAND, J.P.N.

1875. Anecdota Syriaca IV. Leiden: Brill.

LEGG, S.C.E.

1935. Novum Testamentum Graece, Secundum textum westcotto-hortianum, Evangelium secundum Marcum cum apparatu critico novo plenissimo. Oxonii: Clarendoniano.

LOHMEYER, E.

1967. Das Evangelium des Markus: Nach dem Handexemplar des Verfassers durchgesehene Ausgabe. Göttingen: Vandenhoeck \& Ruprecht. KEK 1,2.

LÜHRMANN, D.

1987. Das Markusevangelium. Tübingen: Mohr (Paul Siebeck). HNT 3.

Metzger, B.M.

1994. A textual commentary on the Greek New Testament: A companion volume to the United Bible Societies' Greek New Testament. Second Edition. Stuttgart: Deutsche Bibelgesellschaft. 
Plumley, J. M. \& Roberts, C.H.

1976. An Uncial Text of Saint Mark in Greek from Nubia, The Journal of Theological Studies NS 27:34-45.

Ross, J.M.

1983. Some unnoticed points in the text of the New Testament. Novum Testamentum 25(1):59-72.

Stein, R.H.

2008. Mark. Grand Rapids (MI): Baker Academic. BECNT.

SWANSON, R.

1995. New Testament Greek Manuscripts: Variant readings arranged in horizontal lines against Codex Vaticanus: Mark. Sheffield: Academic Press Pasadena CA: William Carey International Academic Press.

TAYLOR, V.

1966. The Gospel according to Saint Mark: The Greek text with introduction, notes, and indexes. London etc: Macmillan - New York: St Martin's.

WESTCOTT, B.F. \& HORT, F.J.A.

1881. The New Testament in the original Greek. Vol I, Text. Cambridge - London: Macmillan.

WEBER, R.

1975. Biblia Sacra, iuxta vulgatam versionem, editio altera emendata. Tomus I. Stuttgart: Würtembergische Bibelanstalt.

WISSE, F.

1982. The profile method for the classification and evaluation of manuscript evidence, as applied to the continuous Greek text of the Gospel of Luke. Grand Rapids (MI): Eerdmans. StD 44.

Keywords

Gospel of Mark

Textual criticism

Fenton Hort

Priority Western text
Trefwoorde

Evangelie volgens Markus

Teks kritiek

Fenton Hort

Voorkeur Westerse teks 